\title{
CORRECTION
}

\section{Correction to: Influence of a cobalt-based wire injection in austenitic coating deposited via CW-GMAW}

\author{
Tárcio dos Santos Cabral ${ }^{1}$. Sileno Espíndula Dias ${ }^{1}$ - Ademir Angelo Castro Filho ${ }^{1}$ Paola Evelen Costa Baia ${ }^{1}$. \\ Diego Jorge Alves Borges ${ }^{1}$. Eduardo de Magalhães Braga ${ }^{1}$
}

Received: 15 January 2018 / Accepted: 16 August 2018 / Published online: 8 October 2018

(c) The Brazilian Society of Mechanical Sciences and Engineering 2018

\section{Correction to: Journal of the Brazilian Society of Mechanical Sciences and Engineering (2018) 40:461 \\ https://doi.org/10.1007/s40430-018-1384-1}

In the original publication, the co-author's surname has been published incorrectly as "Sileno Espíndola Dias". The correct name should read as "Sileno Espíndula Dias"

The original article has been corrected.

Technical Editor: Márcio Bacci da Silva.

The original article can be found online at https://doi.org/10.1007/ s40430-018-1384-1.

Tárcio dos Santos Cabral

tarcio_cabral@yahoo.com.br

Sileno Espíndula Dias

sileno.dias@itec.ufpa.br

Ademir Angelo Castro Filho

eng.angelo80@gmail.com

Paola Evelen Costa Baia

paolabaia@hotmail.com

Diego Jorge Alves Borges

diego.jborges70@gmail.com

Eduardo de Magalhães Braga

edbraga@ufpa.br

1 Universidade Federal do Pará (UFPA), Belém, Pará, Brazil 